\title{
УДК:632.51:582.794.1+632.954 https://doi.org/10.53040/gppb7.2021.90 \\ ОСОБЕННОСТИ СТАТУСА БОРЩЕВИКА СОСНОВСКОГО В УКРАИНЕ И ХАРАКТЕРИСТИКА ЛИКВИДАЦИИ ОПАСНОГО ВИДА СОРНЯКА В ЧЕРНОВИЦКОЙ ОБЛАСТИ
}

\author{
Соломийчук М.П. \\ Украинская научно-исследовательская станция карантина растений ИЗР НААН, Черновиьь, \\ Украина, e-mail: ukrndskr.zam@gmail.com
}

\begin{abstract}
The pest risk analysis (PRA) was carried out for Sosnowsky's hogweed to determine the ability of the species to be a quarantine object by analyzing the available scientific data. According to the results of the PRA, Sosnowsky's hogweed can be classified as a regulated weed and socially dangerous to human and animal health, highly aggressive in spread, and extremely difficult to eradicate in many areas, where it is widespread in small numbers. It allows to apply measures to it as for any quarantine plant: to control its appearance and completely eradicate it's entry source. The results of developed method have been proposed using the example of town Chernivtsi. Weed density have decreased from 47,8 and 43,5 plants to 4,8 and 1,2 plants on $1 \mathrm{~m}^{2}$ in a number of hotbeds. These measures allowed to decrease the quantity of Sosnovsky's hogweed in some hotbeds by more than 25 times.
\end{abstract}

Key words: regulated pest, phytosanitary risk analysis, weeds, Sosnovsky's hogweed, herbicides, destructor, efficiency.

\section{Введение}

Борщевик Сосновского (Heracleum sosnowskyi Manden.) - многолетнее растение семейства Aріaceae. Растение было занесено в Украину как сельскохозяйственная кормовая культура. Но борщевик Сосновского сейчас несет значительную угрозу как для сельского хозяйства, так и для здоровья людей $[1,2,5,10]$. Захватывая новую площадь, он подавляет другую растительность, нарушает нормальное естественное функционирование местных экологических систем и создает вокруг себя собственную экосистему, неприемлемую для природы той или иной местности. Одно монокарпическое растение способно ежегодно давать от 15-20 тыс., в отдельные годы и до 100 тыс. жизнеспособных семян. В почве семена борщевика могут сохранять жизнеспособность 3-5, иногда 10-15 лет $[6,7]$. При контакте человека с растением могут получатся ожоги, которые трудно заживают. Причина ожогов фурокумарины - вещества, резко повышающие чувствительность организма к ультрафиолетовым лучам. Сильные ожоги формируются при контакте растения с влажным телом в жаркие солнечные дни $[1,3,9]$.

Распространение борщевика Сосновского в Украине в последнее время приобретает неконтролируемый и хаотический характер. Экспансия этого инвазивного сорняка охватывает значительные территории Западной и Центральной Украины [7, 9]. Фактором, который может сдержать дальнейшее распространение этого адвентивного для флоры Украины сорняка, могло бы стать предоставление ему статуса карантинного объекта. Потенциальная опасность этого вида дает все основания относить борщевик Сосновского к категории карантинных сорняков на территориях многих областей, где он отсутствует или не имеет широкого распространения.

За рубежом, в странах, подверженных экспансии борщивика Сосновского (Польши, Германии, Эстонии, Латвии), согласно Международной конвенции по карантину и защите растений этот вид зачислен к карантинным объектам, следовательно, является сорняком, подлежащим полному уничтожению $[2,4,6]$. Есть ряд стран, где он не входит в перечень карантинных организмов, однако имеет статус инвазивного вида. Понятие «инвазивный вид» - это чужеродный вид, который имеет большую способность к расселению, распространяется естественным путем или с помощью человека и представляет значительную угрозу для флоры и фауны определенных экосистем, конкурируя с аборигенными видами за экологические ниши, а также вызывая гибель местных видов. Борщевик Сосновского внесен в Перечень инвазивных чужеродных видов Европейского Союза, а также Список А2 ЕОКЗР, раздел «Инвазивные растения» $[2,4,5]$. В нашей стране, несмотря на то, что уже длительное время борщевик Сосновского есть чрезвычайно проблемным видом, он не имеет статуса карантинного объекта. 
В ряде стран СНГ борщевик Сосновского, начиная с 40-х годов, является сельскохозяйственной культурой и включен в классификаторы сельскохозяйственной продукции, что делает невозможным его внесения в списки сорняков. Однако в течение последних 5-10 лет в некоторых из них его изъяли из этих перечней и перевели в статус вредного организма $[1,2,6]$. Учитывая вышеупомянутое, основной целью работы было проанализировать борщевик Сосновского как объект регулирования с определением способности вида быть карантинным объектом путем анализа имеющихся научных данных.

\section{Материалы и методы}

Анализ фитосанитарного риска проводили согласно Стандартам Европейской и Средиземноморской организации карантина и защиты растений (ЕОКЗР / Эрроу) и Международным стандартам по фитосанитарным мерам (МСФО) [10, 12, 13]. Исследования проводились в 2016-2020 гг. В очагах борщевика Сосновского города Черновцы. Для определения засоренности посевов использовали количественный метод, основанный на подсчете количества сорняков на учетных площадках. После подсчета количества сорняков определяли их среднее количество на 1 м $^{2}$ [8].

\section{Результаты и обсуждение}

Как известно из официальных данных, ежегодно в Государственною службу Украины по вопросам безопасности пищевых продуктов и защиты потребителей поступают обращения относительно карантинного статуса инвазивной растения - борщевика Сосновского и отнесение его к перечню регулируемых вредных организмов. Еще в 2015 г., в то время Государственная ветеринарная и фитосанитарная служба Украины провела Анализ фитосанитарного риска (АФР) для определения соответствия борщевика Сосновского критериям карантинного организма и возможного включения его в перечень регулируемых вредных организмов [10, 12].

Общий вывод проведения АФР: вид борщевик Сосновского не соответствует критериям карантинного вредного организма или регулируемого не карантинного вредного организма для зоны АФР (Украина) и не может быть включен в национальный Перечень регулируемых вредных организмов. Результаты проведенного АФР обнародован на официальном сайте службы [11].

Последний анализ официальных обследований территорий для выявления растений борщевика Сосновского во всех областях Украины было проведено до начала его АФР, в 2014 Вследствие очаги борщевика Сосновского обнаружено в 15 областях Украины на площади 2470,95 га, в основном на землях несельскохозяйственного назначения (85 \%). Однако, как показывают исследования, эти данные давно устарели и значительно различаются от фактических площадей. Так, в качестве примера, согласно данным Государственной фитосанитарной службы в Черновицкой области, площадь борщевика Сосновского в городе Черновцы в 2015 г. составила 8,5 га. Фактические обследования города Черновцы в 2016-2018 годах показали, что борщевик Сосновского занимал территорию площадью 83,1 га. При подсчете количества имеющихся растений сорняков на единицу площади обнаружено очаги, где плотность стояния растений достигала более 40 шт./м². Аналогичная ситуация характерна и для других регионов Украины.

Не претендуя на «утверждение последней инстанции», мы попытались определить возможность вида быть карантинным объектом, путем анализа имеющихся научных данных и применения упомянутой выше терминологии.

На подготовительном этапе АФР объект всесторонне изучают по следующим направлениям: наличие или отсутствие объекта в ареале АФР; происхождения и географическое распространение; биологические особенности и морфологическое строение; обнаружение и идентификация; возможные пути распространения; вредность и экономическое значение $[10,12,13]$. По этим пунктам борщевик Сосновского изучен достаточно глубоко и широко. Как уже отмечалось, этот вид сознательно занесен на территорию Украины, где он проявив значительное доминирование в экосистемах, а также высокую фитотоксичность и угрозу здоровью человека.

Оценка потенциала конкурентоспособности и возможности проникновения на новые территории растения включает 16 пунктов $[12,13], 8$-ми из которых борщевик Сосновского отвечает: быстрое достижение репродуктивной зрелости, регулярное и обильное плодоношение, быстрое наращивание большой вегетативной массы, устойчивость к агротехнических мероприятиям, распространение плодов и семян ветром, водой и животными, а также частое выявление вида на новых территориях. 
Оценка потенциальной возможности акклиматизации и расширение площадей сорняка включает определение его границ, которое проводят на основе принципа лимитирующих факторов, путем сравнения индексов агроклиматических зон имеющегося и потенциального ареалов. Для очень многих областей он набирает по этому показателю 5 баллов из 6 возможных. Это обусловлено наличием климатических условий в ареале АФР, которые совпадают с климатическими условиями ареала этого растения, а также частый занос рассматриваемого сорняка за границу его первичного ареала.

Оценка потенциальной экономической вредоносности от заноса включает 9 пунктов, из которых борщевик Сосновского соответствует 6: ухудшение технологических качеств урожая при засорении (посевы кормовых многолетних трав) снижение продуктивности пастбищ и лугов, садов (вытесняет аборигенные луговые виды растений); негативное влияние на здоровье животных (проблемы с вскармливанием молодняка у коров, питающихся силосом с борщевика) негативное влияние на здоровье людей (травмы или ожоги при контакте с растениями) возможность быть растением-хозяином для вредителей культурных растений; изменение состава природного биоценоза (способствует изменению видового состава природных растительных сообществ с замещением аборигенных видов борщевик Сосновского), обесценивание земель.

Итоговую оценку потенциальной опасности растения проводят с учетом всех приведенных выше оценок по сумме баллов: потенциал конкурентоспособности вида и возможности проникновения его на новые территории (8 баллов); потенциальная возможность акклиматизации и расширение ареала (5 баллов); потенциальная экономическая вредность (6 баллов). Таким образом, борщевик Сосновского набирает 19 баллов. В соответствии с методикой проведения анализа фитосанитарного риска сумма баллов 15,5 и выше соответствует высоким показателям потенциальной конкурентоспособности, расселения и экономической вредоносности вида. Следовательно, есть все основания относить борщевик Сосновского к категории регулируемых сорняков и социально опасных для здоровья людей и животных, высоко агрессивных в распространении, но чрезвычайно тяжелых в искоренении видов растений на территориях многих областей, где они есть в небольшом количестве.

Таблица 1.Результаты уничтожения очагов борщевика Сосновського выявленных в г Черновцы

\begin{tabular}{|c|c|c|c|c|c|c|c|}
\hline \multirow[b]{2}{*}{ Координаты точек } & \multirow[b]{2}{*}{ Название } & \multicolumn{5}{|c|}{ Плотность стояния растений на м² } & \multirow{2}{*}{$\begin{array}{c}\text { Уменьшение } \\
\text { плотности } \\
\text { стояния растений, } \\
\text { (разы) }\end{array}$} \\
\hline & & 2016 г & 2017 г & 2018 г & 2019 г & 2020 г & \\
\hline N48 20.890 E25 55.561 & $\begin{array}{l}\text { Район ул. } \\
\text { Верховинськая- } \\
\text { Каштановая } \\
\end{array}$ & 43,5 & 19,7 & $\begin{array}{l}1,2- \\
18,4\end{array}$ & $\begin{array}{l}1,2- \\
10,6\end{array}$ & $\begin{array}{l}0,4- \\
12,1\end{array}$ & 3,6 \\
\hline N48 18.901 E26 00.321 & Район ул. Лукьяновича & 47,8 & 22,2 & $2,6-7,8$ & $0,9-4,8$ & $3,1-6,4$ & 7,5 \\
\hline N48 20.407 E25 57.573 & ул В. Александри & 15,3 & 0,7 & 0,2 & 0 & 0 & - \\
\hline N48.333972 E25.938384 & ул. П.Лумумби & 12,5 & 4,2 & 2,7 & 4,5 & 5,7 & 2,2 \\
\hline N48 18.977 E25 58.797 & ул. Ткачука & 11,1 & 14,8 & $\begin{array}{l}8,9- \\
18,7\end{array}$ & 9,4 & 8,6 & 1,3 \\
\hline N48 19.247 E25 56.854 & ул. Хотинська & 7,9 & 3,2 & 0,8 & 0,3 & 0 & - \\
\hline N48 21.162 E25 57.067 & ул. Подковы & 8,7 & 2,3 & 1,1 & 0,4 & 0,2 & 43,5 \\
\hline N48 19.249 E25 54.323 & ул. О.Вильшины & 5,3 & 0 & 0 & 0 & 0 & - \\
\hline N48 19.181 E25 56.408 & $\begin{array}{l}\text { Ул. Хотинськяа } \\
\text { (Шиномонтаж) }\end{array}$ & 10,2 & 0 & 0 & 0,1 & 0 & - \\
\hline N48 20.034 E25 57.200 & ул. Красина & 6,3 & 0 & 0 & 0 & 0 & - \\
\hline N48 19.101 E25 58.494 & ул. Ткачука & 9,3 & 1,6 & 0,4 & 0,1 & 0,3 & 31,0 \\
\hline N48 18.912 E25 58.013 & ул. Речная & 8,6 & 2,1 & 0,6 & 0 & 0 & - \\
\hline $\mathrm{N} 4821.005$ E25 58.129 & ул. Дунайська 48 & 7,7 & 0 & 0 & 0 & 0 & - \\
\hline N 48 19.249 E 2557.139 & ул. Хотинськая-Луговая & 7,8 & 6,5 & 3,1 & 1,9 & $1,8-2,2$ & 3,5 \\
\hline N48 20.3525 E25 56.495 & Школа № 34 & 13,7 & 0,4 & 0,1 & 0 & 0 & - \\
\hline N48 21.165 E25 56.541 & ул. А. Чужбинського & 16,4 & 7,3 & 1,2 & 1,3 & 1,1 & 14,9 \\
\hline N48 35.3721 E25 938100 & Ул. Учительськая & - & - & - & 6,4 & 3,8 & 1,7 \\
\hline
\end{tabular}


В период мониторинга очагов, проведен подсчет количества имеющихся растений борщевика на единицу площади. Для ведения контроля за нагрузкой ценозов сорняком проведен контроль этого показателя в динамике за 5 лет (табл. 1.)

По результатам работы учреждения в направлении уничтожения очагов борщевика Сосновского в городе Черновцы, а также за результатами мониторинга в течение 5-ти лет, можно утверждать об эффективности методов которые были применены. Так, на территориях ул. О.Вильшины, ул. Речная, Школа № 34, ул. Красина, ул. Дунайская, 48 растений сорняков в 2020 году не выявлено, а на территориях ул. В. Александри, ул. Хотинская (Шиномонтаж), ул. Ткачука, ул. И.Подковы обнаружены единичные растения, выросшие из семян. Следует отметить, что за период мониторинга на территориях всех очагов, где проводилась работа, значительно уменьшилась плотность стояния растений от 47,8 и 43,5 растений на $\mathrm{M}^{2}$ до 1,1 и 0,2 растений на $\mathrm{M}^{2}$. Это позволило сократить численность борщевика Сосновского в некоторых очагах более чем в 25 раз.

\section{Выводы}

По результатам анализа фитосанитарного риска можно утверждать, что экономический ущерб, который обусловливает снижение продуктивности пастбищ и лугов, обесценивание земель и изменение видового состава природных биоценозов, а также эффект, который наносит борщевик Сосновского здоровью населения - очень высокий, особенно в перспективе экспансии этого инвазивного вида на большую часть территории. Несмотря на то, что окончательный вывод о включении рассматриваемого инвазивного вида в перечень карантинных объектов является прерогативой государственных служб, можно утверждать, что есть все предпосылки считать целесообразным присвоении борщевик Сосновского статуса регулируемого объекта для территорий, на которых он не имеет настоящее время широкое распространение, и применять к нему меры как для любой карантинного растения - контролировать его появление и полностью уничтожать очаги заноса. При этом фитосанитарные меры будут минимальными, при своевременном применении на определенных территориях, что подтверждается исследованиями.

\section{Литература}

1. КИСЕЛЬОВ, Ю. О., СУХАНОВА, І. П., ПАРАХНЕНКО, В. Г. Адвентивна флора України: географічні особливості поширення. Науковий вісник НЛТУ Украӥни. 2020. Т. 30, № 1. С. 9-12.

2. КОЙНОВА, І. Б. Запобігання розповсюдженню шкідливих бур'янів на українсько-польському пограниччі. Львівська область - регіон сучасного управління комунальними послугами : матеріали Міжнар. науково-практичного семінару. Перемишль, 2013 р. Львів-Перемишль, 2013. С. 45-49.

3. КУШАКОВА, А. С., ТКАЧЕНКО, К. Г., ЗЕНКЕВИЧ, И. Г. Определение компоненттного состава эфирных масел борщевиков Heracleum с использованием хроматораспределительного метода. Химия растительного сырья. 2010. № 4. С. 111-114.

4. ЛАМАН, Н. А., ПРОХОРОВ, В. Н., МАСЛОВСКИЙ, О. М. Гигантские борщевики - опасные инвазивные виды для природных комплексов и населения Беларуси / Ин-т эксперимент. ботаники имени В. Ф. Купревича НАН Беларуси. Минск, 2009. 40 с.

5. ЛЕПЕШКИНА, Л. А., СЕРИКОВА, В. И., МОИСЕЕВА, Е. В. Изучение инвазий борщевика Сосновского (Heracleum sosnowskyi Manden.) в центрах интродукции на примере ботанического сада Воронежского госуниверситета. Сборник научных трудов Sworld. 2013. Т. 44, № 3. С. 32-38.

6. ЛУНЕВА, Н. Н. Борщевик Сосновского в Российской Федерации. Защита и карантин растений. 2014. № 3. C. $12-18$.

7. МАКУХ, Я. П. Ременюк С. О., Мошківська С. В. Біологічні особливості та шляхи контролювання борщівника Сосновського. Карантин $і$ захист рослин. 2014. № 10/11. С. 31-32.

8. Методика випробування і застосування пестицидів / за ред. С. О. Трибеля. Київ : Світ, 2001. 448 с.

9. МОШКІВСЬКА, С. В. Контролювання рослин борщівника Сосновського, що проросли 3 насіння. Карантин і захист рослин. 2015. № 11. С. 9-10.

10. СОЛОМІЙЧУК, М. П. Системний підхід у захисті від небезпечного виду бурянів - Борщівника Сосновського. Захист і карантин рослин : міжвід. темат. наук. зб. 2017. № 63. С. 156-164.

11. Стислий звіт про аналіз фітосанітарного ризику, проведений по відношенню до шкідливого організму борщівника Сосновського (Heracleum sosnowskyi) / Департамент фітосанітарної безпеки Держветфітослужби України. Київ, 2015. 2 с.

12. ISPM 11: Pest risk analysis for quarantine pests, including analysis of environmental risks and living modified organisms / FAO. Rome, 2004. 40 p. URL: http://www.fao.org/3/a-j1302e.pdf

13. ISPM 21: Pest risk analysis for regulated non-quarantine pests / FAO. Rome, 2004. 22 p. URL: http://www.fao.org/3/a-y5722e.pdf 